\title{
PENGELOLAAN DIVERSITAS KARYAWAN DALAM MEMBANGUN KEUNGGULAN KOMPETITIF
}

\author{
Sri Lestari \\ Email: cicimanajemen@gmail.com \\ Program Doktor Ilmu Manajemen (DIM) \\ dan Dosen Fakultas Ekonomi Dan Bisnis Universitas Jenderal Soedirman
}

\begin{abstract}
ABSTRAK
This article entitled management diversity of employees to develop competitive advantage. Currently the business world increasingly tight competition. The company increasingly hard in fighting over scarce resources and consumers. The competition took place at both levels local, regional, national and international level. Companies are able to compete will be the winner in the competition. In the face of environmental conditions that increasingly erratic company should be able to operate optimally, that by having the competitive edge. Diversity can give you an advantage for the company especially in serving customers who are also diverse. HUMAN RESOURCES company that came from many different backgrounds have the talent of individuals and different experiences so that it can give you different ideas and can serve a diverse market anyway. It is certain that the diversity of employees at a company many benefits, however it is not denied that the diversity also poses many challenges. human resources management should plan and manage their employees being multiform in such a way that would give maximum performance for the company. To create this company should apply the principle of total quality management and Total Quality Control in managing their employees.
\end{abstract}

Keywords : human resource management, diversity, Total Quality Management, Total Quality Control

\section{Pendahuluan}

Saat ini persaingan dunia usaha semakin ketat. Perusahaan semakin keras dalam memperebutkan konsumen dan sumberdaya yang langka. Globalisasi yang terjadi telah menjadikan dunia semakin sempit. Hal ini mengakibatkan kegiatan bisnis yang dilakukan di seluruh dunia menjadi tanpa batas geografis. Produk yang dihasilkan di suatu negara dapat dengan mudah diketahui, ditiru dan dikonsumsi oleh negara lain. Karyawan maupun konsumen perusahaan juga dapat berasal dari berbagai golongan, wilayah dan negara. Dalam keadaan demikian perusahaan akan berhadapan dengan orang-orang baru dengan berbagai macam keragaman.

Pengaruh persaingan bisnis sangat signifikan dalam mempengaruhi kinerja bisnis. Persaingan terjadi baik pada tingkat lokal, regional, nasional maupun internasional. Perusahaan yang mampu bersaing akan menjadi pemenang dalam persaingan tersebut. Dalam menghadapi kondisi lingkungan yang semakin tidak menentu perusahaan harus mampu beroperasi secara optimal, yaitu dengan memiliki keunggulan kompetitif. Keunggulan kompetitif diartikan sebagai kelebihan tertentu yang memungkinkan sebuah perusahaan dapat menangani kekuatan-kekuatan pasar dan lingkungan secara lebih baik daripada para pesaingnya (Schermerhorn,1996).

Seiring dengan perubahan lingkungan bisnis, pekerjaan juga berubah menjadi semakin beraneka ragam. Demikian juga karyawan yang ada pada sebuah perusahaan juga menjadi semakin beraneka ragam. Dalam konteks organisasional, keragaman dapat digambarkan sebagai sejumlah karakteristik penting dari manusia yang berpengaruh pada nilai-nilai, kesempatan, dan persepsi individu pada dirinya dan orang lain. Karakteristik ini akan meliputi karakteristik utama (primary characteristics), seperti usia, etnis, gender, kemampuan, ras, dan termasuk karakteristik lainnya (secondary characteristics) yaitu geografi, pengalaman kerja, pendapatan, agama, bahasa, gaya berkomunikasi, status keluarga, gaya bekerja, dan pendidikan. Karakteristik tersebut tentunya akan berbeda antara satu orang dengan orang lainnya, yang selanjutnya akan mempengaruhi cara kerja mereka dan akhirnya akan mempengaruhi perusahaan atau organisasi secara keseluruhan (Titin Hartini,2012). 
Dalam sebuah perusahaan keberanekaragaman karyawan dapat memberikan pengaruh yang positif sehingga dapat menempatkan perusahaan memiliki keunggulan kompetitif, namun demikian juga dapat memberikan pengaruh yang negatif (Mathis dan Jackson, 2000 ). Karyawan adalah aset utama perusahaan yang menjadi perencana dan pelaku aktif dari setiap aktivitas organisasi. Mereka mempunyai pikiran, perasaan, keinginan, status, dan latar belakang pendidikan, usia dan jenis kelamin yang heterogen yang dibawa ke dalam organisasi perusahaan. Karyawan bukan mesin, uang, dan material yang sifatnya pasif dan dapat dikuasai serta diatur sepenuhnya dalam mendukung tercapainya tujuan perusahaan (Malayu,2008). Secara umum karyawan pada semua perusahaan adalah beranekaragam dan mempunyai karakteristik yang berbeda-beda. Dalam menghadapi karyawan yang beraneka ragam, perusahaan harus memiliki strategi dan cara yang khusus sehingga karyawan merasa diperlakukan secara fair.

Keragaman dapat memberikan keuntungan bagi perusahaan terutama dalam melayani pelanggan yang juga beraneka ragam. SDM perusahaan yang berasal dari berbagai latar belakang yang berbeda memiliki bakat individu dan pengalaman yang berbeda-beda pula sehingga dapat memberikan ide-ide yang berbeda-beda dan dapat melayani pasar yang beraneka ragam pula. Dapat dipastikan bahwa keanekaragaman karyawan pada sebuah perusahaan banyak memberikan manfaat, namun demikian tidak dipungkiri bahwa keanekaragaman tersebut juga memunculkan banyak tantangan. Disinilah peran manajemen SDM sangat diperlukan. Manajemen SDM harus merencanakan dan mengelola karyawannya yang beraneka ragam sedemikian rupa sehingga dapat memberikan kinerja yang maksimal bagi perusahaan. Dengan demikian perusahaan akan dapat memiliki keunggulan dalam bersaing. Untuk mewujudkan hal tersebut perusahaan hendaknya menerapkan prinsip Total Quality Management dalam mengelola karyawannya.

\section{Pembahasan \\ Manajemen SDM}

Manajemen SDM adalah ilmu dan seni yang mengatur hubungan dan peranan tenaga kerja agar efektif dan efisien guna membantu terwujudnya tujuan perusahaan. Seiring dengan perkembangan dunia usaha saat ini, pengelolaan SDM juga semakin kompleks. Kesimpulan yang dibuat oleh pemerintah, pengusaha dan pekerja di International Labour Conference pada tahun 2007 menyebutkan bahwa"Perusahaan yang berkesinambungan perlu untuk berinovasi, mengadopsi teknologi ramah lingkungan, mengembangkan keterampilan dan sumber daya manusia, dan meningkatkan produktivitas untuk tetap kompetitif di pasar nasional dan internasional. Mereka juga perlu menerapkan praktek-praktek tempat kerja yang didasarkan pada sikap menjunjung tinggi hak-hak mendasar di tempat kerja dan standar perburuhan internasional, dan membina hubungan manajemen SDM yang baik sebagai hal penting untuk meningkatkan produktivitas dan menciptakan pekerjaan yang layak. Prinsipprinsip ini berlaku untuk semua perusahaan" (www.ilo.org).

Dengan perubahan-perubahan yang terjadi saat ini dan semakin meluasnya masyarakat global, perusahaan menghadapi banyak tantangan yang tidak dihadapi sebelumnya. Kemampuan perusahaan menerapkan atau merubah strategi akan memberikan kompensasi atau memberi manfaat dari perubahan-perubahan yang pada akhirnya akan memberikan keberhasilan dan menjamin kelangsungan hidup perusahaan (Suprihatmi SW, 2008 ).

Contoh sukses dalam pengeloaan SDM dapat diambil dari sukses yang diraih oleh Microsoft Corporation. Presiden komisaris sekaligus Direktur Eksekutif Microsoft William H.Gates telah berhasil menumbuhkan perusahaan ini sejak didirikan pada tahun 1975, menjadi berkembang dan mempekerjakan tak kurang dari 15.000 karyawan, dengan rata-rata usia karyawan 31,2 tahun pada tahun 1995. Perusahaan yang bermarkas di Redmond Washington ini berhasil mempertahankan peringkatnya diantara perusahaan-perusahaan paling dikagumi dan seringkali terpilih sebagai perusahaan paling inovatif di AS. Perusahaan ini mengeluarkan produknya hingga 50 macam dalam setahun, termasuk versi-versi internasionalnya.

Hal ini terjadi karena keberhasilan dalam manajemen SDM yang dilakukan oleh William H.Gates. Gates menyadari keterlibatan dalam industry pada semua lini produknya akan menjadi kadaluwarsa dalam lima tahun. Oleh karena itu 
Microsoft memerlukan karyawan yang berbobot dalam jumlah yang banyak dan beraneka ragam. Gates, selalu bertindak atas dasar premis bahwa perusahaan bisa sukses karena karyawannya dan menganggap masalah perekrutan karyawan merupakan masalah yang paling penting dalam menjalankan bisnisnya. Hal ini menyebabkan Mikrosoft banyak melakukan rekrutmen dan penerimaan karyawan. Mencari dan merekrut karyawan terbaik merupakan prioritas nomor satu di Mikrosoft. Microsoft merekrut karyawan baru dari 137 kampus empat kali setahun, mewawancarai 7.400 pelamar dari seluruh dunia dan akhirnya menerima 2.000 orang diantaranya (Randall S.Schuler dan Susan E. Jackson,1997).

Pada contoh kasus di atas William H.Gates benar-benar dapat menjadi contoh seorang pemimpin yang baik, yang dapat mempergunakan wewenang dan kepemimpinannya untuk mengarahkan orang lain serta bertanggungjawab atas pekerjaannya dalam mencapai tujuannya. Kepemimpinan William H.Gates benar-benar mencerminkan gaya seorang pemimpin yang dapat mempengaruhi bawahannya, agar mau bekerjasama dan bekerja efektif sesuai dengan perintahnya. William H.Gates dapat menerapkan asas-asas kepemimpinan yang bersikap tegas dan rasional, bertindak konsisten dan berlaku jujur dan adil sehingga membawa sukses besar bagi Microsoft di seluruh dunia.

\section{Keanekaragaman Karyawan}

Saat ini Microsoft telah berkembang menjadi salah satu perusahaan informasi terbesar di dunia. Jumlah cabangnya telah meningkat di lebih dari 100 negara, dengan jumlah karyawan yang dimilikinya lebih dari 50.000 orang. Perangkat lunak yang dihasilkannya tersebar di seluruh dunia dan nyaris tanpa pesaing. Kesuksesan Microsoft juga merupakan bukti keberhasilan manajemen dalam mengelola karyawan yang beraneka ragam (anneahira.com).

Hasil penelitian banyak yang menunjukkan bahwa keanekaragaman karyawan yang dimiliki perusahaan akan meningkatkan kemampuan perusahaan dalam hal inovasi produk, menciptakan peluang bisnis baru, maupun kemampuan dalam hal problem solving. Keanekaragaman pengalaman dan perspektif karyawan juga dapat dijadikan sumber dalam membangun keunggulan kompetitif.
Karakteristik yang melekat pada beragamnya sumber daya manusia akan menjadi motivasi dan inspirasi bagi perusahaan untuk mampu menghadapi perubahan bisnis yang terjadi melalui daya kreatifitas dan kemampuan yang lebih untuk melihat suatu masalah dari berbagai sudut pandang. Mengingat bahwa keragaman sumberdaya manusia akan sangat berpengaruh pada pengelolaan bisnis perusahaan, maka seharusnya hal tersebut ditempatkan sebagai salah satu isu yang menjadi prioritas utama untuk diperhatikan oleh pihak menajemen perusahaan. Sejumlah literatur telah menyebutkan manfaat yang dapat diperoleh perusahaan dengan melakukan pengelolaan yang baik berkenaan dengan keragaman sumber daya manusia (Titin Hartini,2012).

Thomas dan Ely (1996) dalam (Titin Hartini,2012) menyebutkan bahwa dengan mengelola keragaman sumber daya manusia dengan baik, perusahaan dapat meningkatkan profitabilitasnya, go beyond financial measure untuk mencapai pembelajaran, meningkatkan kreatifitas, meningkatkan pertumbuhan organisasi dan individual, dan meningkatkan kemampuan perusahaan untuk melakukan penyesuaian secara cepat serta untuk melakukan perubahan dengan sukses.

Namun demikian tidak dapat dipungkiri bahwa meningkatnya keragaman sumber daya manusia dalam suatu perusahan juga memiliki sisi negatif, seperti kesulitan untuk berkomunikasi serta meningkatnya ketegangan dan konflik di tempat kerja, akan tetapi kekuatan dari manfaat yang diperoleh dari keragaman menjadi alasan bagi perusahaan atau organisasi untuk menempatkan keragaman sebagai suatu persoalan strategi sumber daya manusia (Mathis dan Jackson, 2000 dalam Titin Hartini,2012 ).

Apalagi dalam lingkungan bisnis yang semakin mengglobal seperti saat ini. Dengan semakin berkembangnya hubungan lintas negara dewasa ini, organisasi seringkali dihadapkan kepada masalah inter-kultural. Dalam kerjasama 
multinasional, baik joint-ventura, aliansi strategis, merger, maupun akuisisi, kedua belah pihak dihadapkan kepada perbedaan kultur yang kadang-kadang sangat berlawanan, sehingga dibutuhkan pemahaman kultur yang lebih mendalam untuk mengatasi hambatan-hambatan yang timbul (Kusdi, 2011). Dalam kondisi demikian keanekaragaman karyawan yang dimiliki perusahaan sangatlah penting.

Agar dapat memperoleh karyawan yang beragam maka peran manajemen SDM dalam mendapatkan tenaga kerja merupakan masalah yang urgen. Pengadaan (procurement) adalah fungsi operasional pertama manajemen SDM. Pengadaan karyawan merupakan masalah penting, sulit, dan kompleks karena untuk mendapatkan dan menempatkan orang-orang yang kompeten, serasi, serta efektif tidaklah mudah. Karyawan adalah aset utama perusahaan yang menjadi perencana dan pelaku aktif dari setiap aktivitas organisasi. Mereka mempunyai pikiran, perasaan, keinginan, status, dan latar belakang pendidikan, usia, dan jenis kelamin yang heterogen yang dibawa ke dalam organisasi perusahaan. Karyawan yang cakap, mampu, dan terampil, belum menjamin produktivitas kerja yang baik, kalau moral kerja dan kedisiplinannya rendah. Mereka baru bermanfaat dan mendukung terwujudnya tujuan perusahaan jika mereka berkeinginan tinggi untuk berprestasi. Karyawan yang kurang mampu, kurang cakap, dan tidak terampil mengakibatkan pekerjaan tidak selesai tepat pada waktunya (M alayu,2008). Hal ini yang menyebabkan masalah perekrutan karyawan merupakan masalah yang paling penting dalam menjalankan bisnis bagi Microsoft Corporation.

\section{Keunggulan Bersaing dan Total Quality Control}

Ada banyak perspektif yang berbeda dalam fungsi organisasi. Tema yang muncul dari studi keunggulan antara lain (1) menetapkan tujuan dan misi bagi organisasi dan memastikan bahwa semua sistem-sistem yang konsisten dengan misi; (2) menciptakan struktur organisasi yang konsisten dengan tujuan organisasi dan memaksimalkan fleksibilitas; (3) merancang pekerjaan dengan cara yang akan memungkinkan staf untuk menggunakan keahlian dan kreativitas mereka; (4) mengembangkan rencana sumber daya manusia yang menghormati keberagaman; (5) merekrut dan mempertahankan staf terbaik berkualitas dan paling produktif; (6) pemantauan, evaluasi, dan memberikan umpan balik tentang kinerja staf dengan cara yang mengarah untuk perbaikan terus-menerus dan tingkat produktivitas yang tinggi; (7) menunjukkan komitmen untuk kinerja tinggi dengan menghadiahi staf produktif;

mengumpulkan data dan informasi tentang layanan yang akan memungkinkan evaluasi dan peningkatan program berkesinambungan; (9) penganggaran dan pembiayaan organisasi dengan cara yang konsisten dengan misi; dan (10) secara berkala mengevaluasi organisasi dan kinerja manajemen.

Keunggulan organisasi ini akan dapat menciptakan keunggulan bersaing bagi perusahaan. Porter (1992) menyampaikan bahwa keunggulan bersaing tumbuh dari nilai yang dapat diciptakan perusahaan bagi pembelinya. Nilai itu dapat berbentuk harga yang lebih rendah dibandingkan dengan harga pesaing atas manfaat yang setara atau perolehan manfaat yang unik yang lebih dari sekedar mengimbangi harga premium. Keunggulan bersaing bersumber dari banyak ragam kegiatan yang dilakukan perusahaan dalam mendesain, membuat, memasarkan, mendistribuskan, dan mendukung produknya. Masing-masing kegiatan ini dapat mempengaruhi posisi biaya relatif perusahaan dan menciptakan landasan diferensiasi.

Porter juga (1992) menyampaikan lima kekuatan persaingan yaitu masuknya pendatang baru, ancaman produk pengganti, kekuatan tawar menawar pembeli, kekuatan tawar menawar pemasok (suppliers), serta persaingan diantara para pesaing yang ada -mencerminkan kenyataan bahwa persaingan dalam suatu industri tidak 
hanya terbatas kepada para pemain yang ada. Pelanggan, pemasok, produk pengganti,serta pendatang baru potensial semuanya merupakan pesaing bagi perusahaan-perusahaan dalam industri dan dapat lebih atau kurang menonjol tergantung pada situasi tertentu. Dalam menghadapi lima kekuatan persaingan tersebut, perusahaan dipastikan akan semakin kuat dalam memenangkan persaingan jika mempunyai karyawan yang semakin beragam.

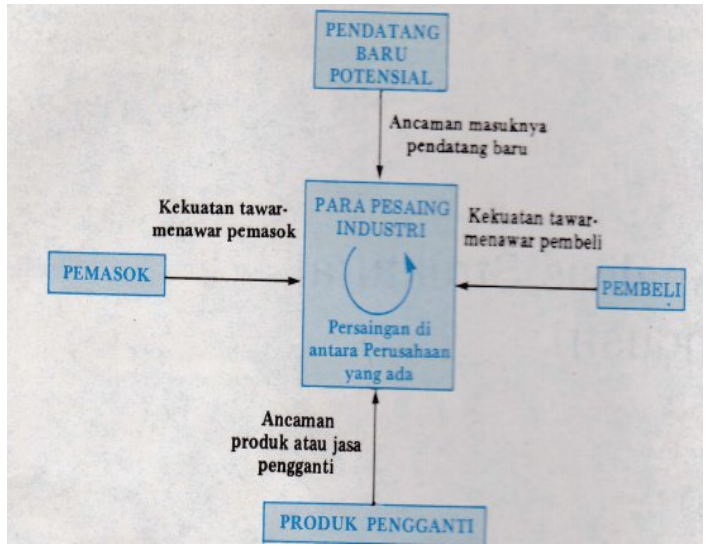

Gambar 1. Kekuatan-kekuatan yang mempengaruhi persaingan industri

Kelima kekuatan yang mempengaruhi persaingan industri dapat dijelaskan sebagai berikut Porter (1992):

1) Ancaman Pendatang baru

Pendatang baru pada suatu industri membawa kapasitas baru, keinginan untuk merebut bagian pasar, serta seringkali juga sumber daya yang besar. Akibatnya harga dapat menjadi turunatau biaya membengkak sehingga mengurangi kemampulabaan.

2) Tekanan dari produk pengganti

Semua perusahaan dalam suatu industri bersaing, dalam ati yang luas, dengan industriindustri yang menghasilkan produk pengganti. Produk pengganti membatasi laba potensial dari industri dengan menetapkan harga pagu (ceiling price) yang dapat diberikan oleh pengusaha dalam industri.

3) Kekuatan tawar menawat pembeli

Pembeli bersaing dengan industri dengan cara memaksa harga turun, tawar menawar untuk mutu yang lebih tinggi dan pelayanan yang lebih baik serta berperan sebagai pesaing satu sama lain. Semua dengan mengorbankan kemampulabaan industri.

4) Kekuatan tawar menawar pemasok

Pemasok dapat menggunakan kekuatan tawar menawar terhadap para peserta industri dengan mengancam akan menaikkan harga atau menurunkan mutu produk atau jasa yang dibeli.Pemasok yang kuat karenanya dapat menekan kemampulabaan industri yang tidak mampu mengimbangi kenaikan harganya.

5) Persaingan diantara pesaing yang ada

Tingkat persaingan di kalangan pesaing yang ada berbentuk perlombaan untuk mendapatkan posisi dengan menggunakan taktik-taktik seperti persaingan harga, perang iklan, introduksi produk, dan meningkatkan pelayanan atau jaminan kepada pelanggan. Persaingan terjadi karena satu atau lebih pesaing merasakan adanya tekanan atau melihat peluang untuk memperbaiki posisi. Pada kebanyakan industri gerakan persaingan oleh satu perusahaan mempunyai pengaruh yang besar terhadap para pesaingnya dan dengan demikian dapat mendorong perlawanan atau usaha untuk menandingi gerakan tersebut.

Perusahaan yang memiliki karyawan yang beragam lebih tahan terhadap persaingan. Dengan karyawan yang beraneka ragam perusahaan akan lebih luwes berhubungan dengan pembeli, pemasok dan pesaingpesaingnya. Perusahaan akan diuntungkan pada saat melayani pelanggan yang juga beragam. Semakin perusahaan mempunyai karyawan yang beragam maka kemampuan perusahaan dalam beradaptasi dengan lingkungan semakin besar. Perusahaan juga dapat melayani konsumen dengan jangkauan yang lebih luas. Identifikasi keragaman dapat berupa keragaman ras, jenis kelamin, tingkat pendidikan, agama, kelompok etnis, usia, gaya kognitif, kepribadian, senioritas dan sebagainya.

Menurut Sila et al. (2007) dalam Munizu (2010) Total Quality Management (TQM) memainkan peranan yang sangat penting dalam meningkatkan kekuatan daya saing perusahaan. Di dalam pasar global yang berubah secara terus menerus, disamping pengiriman yang cepat (speed of delivery), kualitas produk juga menjadi salah satu elemen yang penting bagi perusahaan untuk dapat bersaing (competition). TQM adalah salah satu bentuk praktek 
manajemen terbaik dalam perusahaan yang menekankan paradigma kualitas secara menyeluruh dalam perusahaan.

Lebih lanjut disebutkan TQM merupakan pendekatan yang seharusnya dilakukan organisasi masa kini untuk memperbaiki kualitas produknya, menekan biaya produksi dan meningkatkan produktivitasnya. Implementasi TQM juga berdampak positif terhadap biaya produksi dan terhadap pendapatan (Gaspersz, 2005 dalam Munizu (2010). Bukti lain juga menunjukkan bahwa perusahaan yang mengejar praktek terbaik TQM dapat mencapai keuntungan yang lebih tinggi dan cashflowsnya sebaik nilai pemegang saham yang lebih besar (Corbett and Rastrick, 2000 dalam Munizu (2010).

Heizer and Render (2004) dalam Munizu (2010) berpendapat bahwa kualitas terutama mempengaruhi perusahaan dalam empat hal, yaitu: (1) biaya dan pangsa pasar: kualitas yang ditingkatkan dapat mengarah kepada peningkatan pangsa pasar dan penghematan biaya, keduanya juga dapat mempengaruhi profitabilitas; (2) reputasi perusahaan: reputasi perusahaan mengikuti reputasi kualitas yang dihasilkan. Kualitas akan muncul bersamaan dengan persepsi mengenai produk baru perusahaan, praktekpraktek penanganan pegawai, dan hubungannya dengan pemasok; (3) pertanggungjawaban produk: organisasi memiliki tanggung jawab yang besar atas segala akibat pemakaian barang maupun jasa; dan (4) implikasi internasional: dalam era teknologi, kualitas merupakan fokus perhatian dalam bidang operasional. Apabila produk yang dihasilkan berkualitas, maka akan berimplikasi pada meningkatnya permintaan produk di pasar inter nasional

Agar dapat dihasilkan produk yang berkualitas tinggi maka dalam menghasilkan barang dan jasa sebaiknya diterapkan prinsip "Pengendalian Mutu Terpadu atau Total Quality Control (TQC)". Dasar TQC adalah mentalitas, kecakapan dan manajemen partisipatif dengan sikap mental yang mengutamakan kualitas kerja. Mentalitas adalah kesediaan bekerja sungguhsungguh, jujur dan bertanggungjawab melaksanakan pekerjaannya. Malayu (2012) mendefinisikan Pengendalian Mutu Terpadu yaitu suatu sistem yang efektif untuk mengintegrasikan usaha-usaha pengembangan kualitas, pemeliharaan kualitas, dan perbaikan kualitas atau mutu dari berbagai kelompok dalam organisasi, sehingga meningkatkan produktivitas dan pelayanan ke tingkat yang paling ekonomis yang menimbulkan kepuasan semua langganan. TQC berorientasi pada mutu, dimana yang dimaksud dengan mutu/kualitas adalah a) disesuaikan dengan permintaan; b) sistemnya adalah pencegahan sejak awal dikerjakan dengan benar; c) standarnya adalah tidak ada cacat/harus tidak ada kesalahan; d) ukurannya adalah biaya untuk mencapai kualitas. Prinsip-prinsip kualitas adalah : a) kepuasan pemakai, jadi berorientasi pada pemakai, bukan pada standar; b) mencakup kualitas dari semua pekerjaan; c) merupakan tanggungjawab setiap orang sehingga sejak awal harus dilaksanakan dengan benar, sedangkan kualitas mencakup kualitas : a) produk, orang, dan aktivitas; b) biaya; c) pengiriman; d) keselamatan; dan e) moral. Dalam konsep manajemen, TQC selain bertujuan mengendalikan mutu produk, juga termasuk usaha perbaikan struktur dan manajemen organisasi.

Kualitas diyakini merupakan salah satu aspek terpenting guna mencapai keunggulan kompetitif dalam persaingan global. Perusahaan yang ingin menang dalam persaingan dan berorientasi konsumen harus fleksibel dan terus melakukan perbaikan kualitas secara berkelanjutan. Hal ini akan lebih mudah dilakukan jika di perusahaan tersebut terdapat karyawan dengan kriteria yang berbeda-beda atau karyawan yang beraneka ragam.

\section{Kesimpulan}

Persaingan dunia usaha semakin ketat memaksa perusahaan untuk mencari cara dalam menjalankan perusahaan dengan seefisien mungkin dan mempunyai strategi yang tepat untuk dapat mengatasi keadaan lingkungan. Dalam hal ini peran manajemen Sumber Daya manusia semakin penting. Adanya globalisasi menyebabkan pasar produk perusahaan semakin beraneka ragam, oleh karena itu perusahaan dituntut untuk menghasilkan produk yang berkualitas dan beraneka ragam pula. Oleh karena itu perusahaan sebaiknya menerapkan sistem pengendalian mutu terpadu dan Total Quality Manajemen dalam menjalankan 
usahanya. Adanya pasar yang beraneka ragam menyebabkan keuntungan yang besar jika perusahaan juga memili karyawan yang beraneka ragam pula, karena dengan demikian perusahaan akan dapat mengerti selera dan kebutuhan konsumen.

\section{Saran}

Perusahaan akan semakin unggul dalam persaingan jika mempunyai karyawan yang beraneka ragam. Oleh karena itu dalam proses pengadaan karyawan hendaknya setiap

\section{Daftar Pustaka}

perusahaan mempertimbangkan untuk merekrut karyawan yang beraneka ragam. Perlu juga diperhatikan bahwa disamping manfaat yang demikian besar dengan adanya penganekaragaman karyawan tetap ada hal yang merugikan yang dapat muncul dari keadaan ini. Oleh karena itu perusahaan hendaknya memperhatikan dengan mengeliminir efek buruk dengan adanya keanekaragaman tenaga kerja.

Musran Munizu, 2010, Jurnal Manajemen dan Kewirausahaan, Vol.12, No. 2, 185-194

Michael E. Porter, 1992, Keunggulan Bersaing, Erlangga, Jakarta

Michael E. Porter, Agus Maulana, 1992, Strategi Bersaing, Erlangga, Jakarta

Malayu Hasibuan, Manajemen Sumber daya Manusia, 2008, Bumi Aksara, Jakarta

Schermerhorn, J. R., 1996, Management $5^{\text {th }}$ ed., John Willey \& Sons, Inc, New York

Schuler, Randall S and Jackson, Susan E. 1997. Manajemen Sumber Daya Manusia: Menghadapi abad ke 21 edisi keenam jilid 1. Erlangga, Jakarta

Suprihatmi SW, 2008, Jurnal Ekonomi dan Kewirausahaan Vol. 8, No. 1,: 38 - 50

Titin Hartini, 2012, Mengelola Keragaman Sumberdaya Manusia : Suatu Upaya Mengoptimalkan Kinerja Organisasi, Jurnal Ilmiah STIE MDP. 